\section{P-549 前立腺穿刺吸引梱胞診の有用性の検討}

埼玉社会保険病院 泌尿器科1）

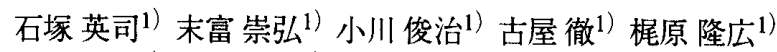
金子昌司 ${ }^{1)}$ 石井 泰憲 ${ }^{1)}$

【目的】前立腺癌取扱規約では、吸引生検細胞診は組織診に準ず るものとみなされている。前立腺癌スクリーニングに拀いては、 前立腺穿刺吸引細胞診はその簡便性、安全性、及び外来にて施行 可能である点など多くの利点がある。当科での成績について検討 した。【方法】1995年1月より1999年9月までに、当科外来または入 院中に前立腺癌を疑われ穿刺吸引細胞診を施行された症例のう ち、組織学的検查が併用された 97 例を対象とした。【結果】 97例中 52例 $(53.6 \%)$ が形態学的に前立腺癌と診断された。そのうち細胞 診陽性 (class IV,V) および組織診陽性（癌）とが一致したのは35例（ 81.8\%) であった。2例 (4.5\%) は疑陽性 (class III)、6例 (13.6\%) は偽 陰性 (class I,II)であった。1例は、細胞診のみ陽性で組織診では atypical hyperplasiaであったが、癌と診断した。組樴診陰性（非癌） 例のうち細胞診陰性 (class I,III) は、28例 (68.3\%) であり、class IIIが 13例 (31.7\%) であった。前立腺細胞不採取例は12例 (12.5\%) あった。 細胞診の結果と組織学的分化度や臨床病期との相関や有意差はな かった。急性前立腺炎や出血等の合併症は認められなかった。 【総括】外来で実施可能な前立腺癌のスクリーニング法のひとつ として、前立腺穿刺吸引細胞診は、有用であるといえる。

前立腺㾔 穿刺吸引細胞診

\section{P-551 経直晹的前立腺生検に超音波パワードプラ 法は有用か？}

\section{福岡大学 医学部 泌尿器科1)}

宮嶋哲匡 ${ }^{1)}$ 横山 裕 ${ }^{1)}$ 辻祐治 ${ }^{1)}$

【目的】释直腸的前立腺針生検における超音波パワードプラ法 (PD法) の有用性を検討した.【対象と方法】対象は1998年6月か ら1999年11月の間に, PSA值あるいは直腸診により癌が疑われた ため，われわれの施設で経直腸的前立腺針生検を施行された である. 原則として系統的六分割生検を行い，さらにグレース ケール法 (GS法) およびPD法で癌が疑われた部位から標本を採 取した。標本の病理組織学的所見と超音波所見とを比較し，それ ぞれの方法の sensitivity, specificity, positive predictive value (PPV) を算出した.【結果】90例から592標本（癌：113，境界病変：47, 良性病変：432）が採取され，38例が前立腺癌と診断された。境界 病変を除外した場合，それぞれの方法でSensitivity：GS法 63\%/ PD法 42\% / GS法 +PD法 64\%, Specificity：GS法 84\% / PD法 88\% / GS法+PD法 77\%, PPV：GS法 50\% / PD法 48\% / GS法+PD法 $42 \%$, の結果であった。【結諭】PD法での血流信号の増加は, GS 法の低エコー像とともに前立腺癌の超音波所見のひとつである. しかし, もともと癌が疑われる pretest probability の高い対象に対し て行なわれたにもかかわらず，PD法による生検のPPVは $48 \%$ と低 く, 現状では前立腺癌の診断にPD法は有用ではないと考えられた。 前立腺满 生検 超音波断層法

\section{P-550 前立腺生検陰性症例のTUR-P後の病理組織 学的検討}

\begin{abstract}
名古屋大学 医学部 泌尿器科1)

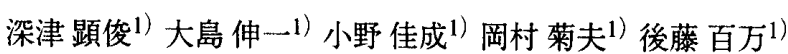
高士 宗久 ${ }^{1)}$ 山田 (申申 $^{1)}$ 犬塚 善博1)

【目的】血清PSAが異常值をとり、生検で癌が証明されず、TUR-P を施行したBPH症例における癌の発生頻度を病理組織学的に検討 した。【対象と方法】1996年8月から1999年10月までに、血清 PSA(TandemR 換算值) $>4.0 \mathrm{ng} / \mathrm{ml}$ で経直腸的超音波ガイド下6分割針 生検を施行した241症例中、160症例で癌が検出されなかった。 のうち排尿障害のためTUR-Pを施行した 41 症例を対象とした。結 果】 41 症例中10例に癌が検出された。T1a年8 8 例、Tlbが 1 例、TURP切除標本にても癌が検出されなかったが、術後PSA值が高値を示 したため再生検を施行し癌が検出された例(T1c)が1例あった。病 理所見が中分化であったTla1例とT1b及びT1cの3症例に対して根 治的前立腺全摘術を施行し、他のTla7症例は経過観察のみを行つ ている。また、TUR-P前PSA值は癌症例 $16.3 \mathrm{ng} / \mathrm{ml}$ 、非癌症例 14.5ng/mで有意差を認めなかったが、PSADはそれぞれ0.41、0.25 と有意 $(\mathrm{P}=0.03)$ に癌症例で高かった。結諭】 41 症例中10例に癌が 検出されたが8例がT1aであった。またTUR-P後もPSA值が高値の 症例は、再生検の必要があると考えられた。
\end{abstract}

前立腺癌 PSA TUR-P

\section{P-552 前立腺癌の検出における造影カラードプラ 法の検討}

\begin{abstract}
島根医科大学 泌尿器科 1
滋野和志1) 中村繁1（浦上慎司1) 米田 達明1) 椎名 浩昭1) 井川幹夫1)

【目的】超音波用造影剂の使用により超音波カラードプラ（CDUS） の前立腺癌の検出能が向上するか否か検討した．【対象と方法】 1999年10月から11月の間に, 根治的前立腺全摘除術前の前立腺癌 患者 9 人に対して，Levovist ${ }^{R}(300 \mathrm{mg} / \mathrm{ml})$ の持続静注（1.0 2.0 ml $/ \mathrm{min})$ ，また，そのうちの3例にはさらに1,500 mgの急速静注を 行ない腫㰾の造影効果を検討した，超音波画像はビデオに録画し， 術後に摘出標本と比較した.【結果】9例11腫晹中, 8腫場で造影効 果が認められたそそのうち4腫場はCDUSでは血流が観察されず, 造影により血流が観察できた（1腫瘍は急速静注時）。他の3腫瑒 は造影によりCDUSでは不明暸であった血流が明暸となった。 方, 残りの3腫場では造影効果がみられず，そのうち2腫場は内線 の腫韵で，急速静注も追加したが無効であった．【結語】超音波 造影剂はCDUSの前立腺癌の診断能を向上させることが示唆され た。ささら前立腺生検における超音波造影剂の有用性について報 告する.

前立腺菭＼cjkstart超音波造影剤＼cjkstart造影カラードプラ法
\end{abstract}

